\title{
sciendo
}

\section{Multidimensional model of managing older employees: The case of financial service companies in Slovenia}

\author{
Maja Rožman \\ University of Maribor, Faculty of Economics and Business, Maribor, Slovenia \\ maja.rozman1@um.si \\ Vesna Čančer \\ University of Maribor, Faculty of Economics and Business, Maribor, Slovenia \\ vesna.cancer@um.si
}

\begin{abstract}
Future economic growth and competitiveness will increasingly depend on how effectively employers can utilise their ageing workforces. To manage the inevitable changes in demographics, employers need to start preparing for an ageing workforce and developing strategies to manage and retain older employees. The main objective of this paper is to determine the impact of leadership and employee relations on work satisfaction of older employees, as well as to determine the impact of work satisfaction on the work engagement of older employees in financial service companies in Slovenia. To test the hypotheses, the authors used structural equation modelling. The results show that the effects of leadership and employee relations on work satisfaction in the case of older employees in financial service companies in Slovenia are positive, and the effect of work satisfaction on the work engagement of older employees is positive, too.
\end{abstract}

Keywords: employee relations, leadership, older employees, structural equation modelling, work engagement, work satisfaction.

JEL classification: C38, J24.

DOI: 10.2478/crebss-2019-0013

Received: October 08, 2019

Accepted: November 28, 2019

\section{Introduction}

The population is aging and older employees are becoming an important part of the labor market (Davies et al., 2017; Zacher et al., 2018). The entire field of management is evolutionarily changing. Human resources management has to respond to new challenges of the inner and outer environment of the organisation. In the context of demographic changes, management of older people contributes to the forming of new views on the entire field of management and is an important part of a new management paradigm (Beazley et al., 2017). Ageing has become a necessary focus of interest in today's society. Irrespective of age, an employee needs the appropriate 
skills and knowledge to be productive and to help the organisation achieve its strategic objectives (Davies et al., 2017). The aging workforce presents new challenges to management practice and new possibilities for management research (Kulik et al., 2014).

Structural equation modeling (SEM) has been proven useful in exploring the links between constructs in various human resource management (HRM) multidimensional models (Veingerl Čič et al., 2017). Our research focuses on one of the important aspects of the sustainable profitability of a business: the satisfaction and engagement of older employees. Based on the HRM theoretical background, the authors built a conceptual multidimensional model of managing older employees in financial service companies in Slovenia. As the authors wanted to determine the impact of leadership and employee relationship - two important components of work satisfaction of older employees in financial service companies that further shape the level of work engagement of older employees - the conceptual model includes the following constructs: leadership, employee relations, work satisfaction and work engagement. The main objective of this paper is to determine the impact of leadership and employee relations on work satisfaction of older employees, as well as to determine the impact of work satisfaction on the work engagement of older employees in financial service companies in Slovenia.

The findings of research of Yang et al. (2015) based on SEM analysis show that employee relations and leadership have a positive impact on work satisfaction. The authors' findings indicate that older employees have good relationships with their employer and colleagues in the workplace, therefore work in a more supportive work environment, have better health status and are more satisfied (Yang et al., 2015). Another study by Robinson et al. (2004), suggests that work satisfaction is an important driver of work engagement. Additional findings of Egan et al. (2004) show that there is a positive relationship between work satisfaction, work motivation and work engagement.

There is not much literature and research that is based on theoretical knowledge on the topic researched nor studies about impact of leadership and employee relations on work satisfaction in the case of older employees in financial service companies in Slovenia and impact of work satisfaction on work engagement of older employees in these companies. With this research, the authors wanted to fill the above-mentioned gap.

In the following sections, the authors present the literature review on the definition of older employees, human resource management of older employees and ageing in the workplace. The authors also describe the constructs in the conceptual model. Furthermore, the authors present the hypotheses, which are built on the literature review. This is followed by a description of methodology used in our empirical research and the obtained results. The article concludes with the discussion of the main findings, limitations and further research possibilities.

\section{Literature review Definition of older employees}

The answer to the question of when an employee is considered as an "older employee" can be very subjective and difficult. Aging is a complex problem; due to multidimensionality, it is difficult to capture it in a single definition or measure (see, e.g., Peeters et al., 2008; Cleveland, Lim, 2007). For example, Warr (1994) uses the age of 45 to define an older employee, whereas Greller, Stroh (2004), Smyer, Pitt-Catsouphes (2007), define an older employee as someone aged 50 or more. The term "older 
employee" includes employees between the ages of 40 and 50. According to OECD (2000) definition, an older employee is someone who is aged 55 or more. As is visible from these examples the definitions of an older employee in technical literature differ.

\section{Human resource management of older employees}

Workforces are aging across the world, therefore an important strategic task for organizations is to find policies and practices encouraging older employees to remain engaged, motivated, satisfied, productive and healthy (Kooij, Van De Voorde, 2015; Guglielmi et al., 2016). Because motives and abilities change as people age (Kooij et al., 2011), the utility and thus the effects of human resource practices might also change with age (Kooij et al., 2013). According to Kooij, Van De Voorde (2015), human resource practices of organizations can be adapted to the needs of older employees in different ways. Thus, authors Kooij, Van De Voorde (2015); Kooij et al. (2013) summarize that organizations can build competitiveness on rare, valuable and exceptional human talent's resources.

The positive influence of human resource practices on work satisfaction, work engagement, health, and performance is more likely to strengthen with age in companies that support age diversity in the workplace (Moen et al., 2017; Kooij, Van De Voorde, 2015).

Financial services companies that bring together talent from both generations will be able to exploit the benefits of an engaged employees. Thus, financial services companies must find ways to retain older employees. Older employees have many benefits that can provide additional value in the workplace due to their experience and stability. For example, older employees have an important role in acquiring and retaining customers, because they are more experienced about financial matters (see, e.g. May, 2004; Naegele, Walker, 2006).

\section{Ageing in the workplace}

Finance sector can expect a substantial increase of older employees in the forthcoming years. Therefore, it may especially face tensions in matching workers to jobs. This may require rethinking longstanding workplace practices (Sweet, PittCatsouphes, 2010; Davies et al., 2017). The issue of ageing in the workplace has been defined as a "new diversity" because it tests the capacity of organizations to manage changes in the composition of the workforce (Chiesa et al., 2016). According to Zacher et al. (2018), active aging means that as employees age, they (1) continue to show high levels of work engagement and performance; (2) maintain or improve their physical, mental, and social well-being; and (3) experience fair treatment and employment security. As a consequence, older employees are not only able and motivated to work past retirement ages, they also continue to be happy and productive members of the workforce. Cheung and Wu (2013) emphasizes that those employees who have a higher level of successful aging in the workplace, would have higher intentions to stay in the company. Positive aging in the workplace also positively relate to their work satisfaction and work engagement.

\section{Description of constructs in the conceptual model}

Leadership. Managing employees is concerned with making plans and deciding on approaches which to use to make employees perform the way to help the company to achieve their goals (Amagoh, 2009).The appropriate leadership style is important for employee satisfaction. Thus, leaders act to provide satisfaction of their employees or more likely to offer means of satisfaction. Successful leaders understand the needs 
of their employees and persuade them to act in a certain way (Chan, 2019). Research on leadership indicates that, when employers apply effective leadership skills, employees have better work motivation, higher satisfaction, feel less job pressure and pay more attention to the job (Hu et al., 2010). Leadership is a function, which is important at all levels of management, thus leaders play an important role in the active aging process (Zacher et al., 2018). In addition, team members of all ages benefit when leaders structure tasks according to individual age-related abilities and motives, and help teams focus on higher-order goals instead of demographic differences. In this way, leadership plays an important role in employee performance and productivity (see, e.g. Zacher et al., 2018; Profili et al., 2017). Therefore, the authors construct the following hypothesis: $\mathrm{Hl}$ : Leadership has a significant positive impact on the work satisfaction of older employees in financial service companies in Slovenia.

Employee relations. Any organization that wants to succeed in a specific industry must place emphasis on positive employee relations (Abugre, 2017). Employees who have a positive relationship with employer and their colleagues work more efficiently and smarter. They are more likely to do their best in the workplace. This leads to higher productivity, performance and work satisfaction (Anitha, 2014). In addition, Abugre (2017) summarizes that positive employee relationships in companies will enhance or increase employee work satisfaction and consequently employees' intention to stay. Otherwise, negative organisational relationship would increase organisational cynicism, which leads to diminished work engagement and work motivation of employees in companies (Watt and Piotrowski, 2008). Due to demographic change, positive employee relations in the companies between generations are important. Age-diverse teams allow for interactions and knowledge sharing between younger and older employees (Zacher et al., 2018). Age diverse teams should be managed to maximize the positive effects of exchanging different views and perspectives, and to minimize the negative effects of discrimination and age stereotypes (Hertel et al., 2013). According to Ford (2011), Fay, Kline (2011), good employee relations in the workplace lead to higher work satisfaction and productivity. In this way, the following hypothesis is created: $\mathrm{H} 2$ : Employee relations have a significant positive impact on the work satisfaction of older employees in financial service companies in Slovenia.

Work satisfaction and work engagement of older employees. Good work satisfaction in the company can lead to better performance of the employees, which affects the result of the company. Employee satisfaction is considered as the driver of the employee productivity and employee retention. Satisfied employees are a precondition for increasing responsiveness, productivity, quality, and also, customer service (Aver Antoncic, Antoncic, 2011). Successful aging in the workplace is significantly related to work satisfaction. For example, close employee relations in the workplace and adaption of new work roles enhance the sense of control and efficacy of older employees, and these positive self-evaluations will in turn lead to high work satisfaction (Cheung and Wu, 2013). Higher levels of work satisfaction tend to lead to lower levels of absenteeism and better mental and physical health (Hennekam, 2016) and also, lead to higher work engagement (Ford, 2011). Studies that delved into employees' work satisfaction and age show a positive correlation between the two (see, e.g. Aristovnik, Jaklič, 2013). The importance of work satisfaction and engagement is growing all the time in the companies (Dhamija et al., 2019). On the other hand, work engagement represents a positive working state that improves organizational performance. Work engagement significantly influences on employees' performance, turnover intentions and organizational success, therefore it is considered as a key indicator of organizational health (Lu et al., 2016). Work 
engagement is considered "as a positive, fulfilling, work-related state of mind that is characterized by vigour, dedication, and absorption" (Schaufeli et al., 2002). Engaged employees are characterized by high levels of energy and by the strong capability to invest effort in order to fulfil their jobs. They also tend to be more resilient and able to cope effectively with problems (Guglielmi et al., 2016). According to Bakker, Demerouti (2009), highly engaged employees are more positive, help others improve work efficacy, continually improve work-related skills and are highly active. Demographic change increases the pressures on organizations to figure out effective ways of keeping employees engaged across different life stages. Thus, there are good reasons to believe that age might play an important role in determining workplace engagement (Ning, Alikaj, 2019). Therefore, the authors propose the following hypothesis: H3: Work satisfaction of older employees has a significant positive impact on the work engagement of older employees in financial service companies in Slovenia.

\section{Data and methodology}

The main survey that was conducted from January to February 2017 involved 237 large- and medium-sized financial service companies in Slovenia, and from each company, up to three older employees participated in our research. Thus, 704 older employees responded to the questionnaire. In the literature, the definitions of older employees vary (Brooke, 2003; Ilmarinen, 2001) as presented in the section on the definition of older employees. In this paper, employees of $\geq 50$ years of age were defined as older employees.

The respondents indicated on a 5-point Likert-type scale their agreement to the listed statements, where $1=$ strongly disagree and $5=$ completely agree $(1=1$ strongly disagree, 2 = I do not agree, 3 = I partially agree, $4=$ | agree, $5=$ | completely agree ). Items for the leadership construct were formed by Avery et al. (2007), for the employee relations construct by Gunnigle et al. (1998), for the work satisfaction construct by Hayday (2003) and for the work engagement construct by Robinson et al. (2004). Within the empirical part, the authors established the justification to use the factor analysis based on the Kaiser-Meyer-Olkin measure of sampling adequacy (KMO $\geq 0.5$ ) (Kaiser, 1974) and Bartlett's test of sphericity. With the purpose to improve the factors' interpretability and achieve a more even distribution of variance according to the factors, the rectangular rotation Varimax, which maximizes the variance of weight squares in every factor and simplifies the structure by columns, was used (Hair et al., 2010; Manly, 2005). Also, fulfillment of criteria regarding factor loadings ( $n \geq 0.5$ ), communalities of variables ( $h>0.4)$, and eigenvalues of factors $(\lambda \geq 1.0)$ was analyzed (Tabachnick, Fidell, 2013). The quality of the measurement model was measured by the variance explained for a particular construct. The authors checked the reliability of measurements within the scope of inner consistency with Cronbach's alpha coefficient (Chronbach, 1951). As part of the convergent validity, the authors examined average variance extracted (AVE) and composite reliability coefficients $(C R)$, keeping in mind the criteria $A V E>0.5$ and $C R>0.7$ and the criterion $C R>A V E$ (Kock, 2016). In order to check for multicollinearity, the authors used variance inflation factors (VIF), considering the criterion VIF $<5.0$ (Hair et al., 2010). The quality of the structural model was measured by the R-squared and adjusted R-squared coefficients, reflecting the percentage of explained variance of latent variables in the structural model and the Stone-Geisser Q-squared coefficient. Thus, the authors examined the predictability value of the structural model. Acceptable predictive validity in connection with an endogenous latent variable is suggested by $Q^{2}>0$ (Kock, 2015). To test the model, the following rules were also applied: average path 
coefficient (APC, $p<0.05$ ), average R-squared (ARS, $p<0.05$ ), average adjusted Rsquared (AARS, $p<0.05$ ), average block variance inflation factor (AVIF < 5.0), average full collinearity VIF (AFVIF < 5.0), goodness-of-fit (GoF $\geq 0.36$ ), Sympson's paradox ratio (SPR $\geq 0.7$ ), the R-squared contribution ratio (RSCR $\geq 0.9$ ), statistical suppression ratio (SSR $\geq 0.7)$ and nonlinear causality direction ratio (NLBCD $\geq 0.7)$ (Kock, 2016, Tabachnick, Fidell, 2013). To test the hypotheses, the authors used the path coefficient associated with a causal link in the model $(\mathrm{Y})$ and indicator of Cohen's effect $\left(\mathrm{f}^{2}\right)$, with $0.02,0.15$, and 0.35 indicating the small, medium, and large effect sizes (Kock, 2015; Tabachnick, Fidell, 2013). The Statistical Package for the Social Sciences (SPSS) and WarpPLS software were used for data analysis. According to Kock (2016), SEM is based on the linear or non-linear connections between constructs. The results obtained by WarpPLS show that the observed links in our model are non-linear.

\section{Research Analysis Results and Discussion}

The results in Table 1 provided with SPSS 22 show that the most important variable in leadership is good relationship between employees and superiors. The most important variable in employee relations reflects the prevailing trust and cooperation between employees. The most important variable in work satisfaction of older employees is satisfaction with the interpersonal relationships in the company and the most important variable in work engagement of older employees is doing work with passion. Table 1 also shows that the values of the measure of sampling adequacy and the results of Bartlett's test of sphericity for each construct (leadership, employee relations, work satisfaction, work engagement) suggest that the use of factor analysis is justified. The values of all communalities for all four constructs are higher than 0.70; therefore, the authors have not eliminated any variable. Also, all factor loadings are higher than 0.70 and significant at the 0.001 level. For each construct, the onedimensional factor solution was obtained. All measurement scales proved high reliability (all Cronbach's alpha $>0.9$ ). In addition to the results in Table 1, the total variance explained for leadership is $81.8 \%$, for employee relations is $75.2 \%$, for work satisfaction is $78.8 \%$ and for employee work engagement is $85.6 \%$. 
Table 1 Factor analysis results

\begin{tabular}{|c|c|c|c|c|}
\hline Statement & Factor label & $\begin{array}{c}\text { Cronbach's } \\
\text { alpha }\end{array}$ & Communalities & $\begin{array}{l}\text { Factor } \\
\text { loadings }\end{array}$ \\
\hline $\begin{array}{l}\text { I have all necessary information } \\
\text { to perform my work. } \\
\text { I have everything I need to carry } \\
\text { out my work tasks. } \\
\text { I have the possibility of } \\
\text { independent thinking and } \\
\text { decision-making in the } \\
\text { workplace. } \\
\text { The company owner/manager } \\
\text { fosters good relationships } \\
\text { between employees } \\
\text { The company owner/manager } \\
\text { of the company fosters good } \\
\text { relationships between } \\
\text { employees and superiors. } \\
\text { The company owner/manager } \\
\text { emphasizes and encourages } \\
\text { employee motivation in the } \\
\text { workplace. } \\
\text { The company owner/manager } \\
\text { ensures the work satisfaction } \\
\text { and well-being of employees. } \\
\text { In the company, we have the } \\
\text { possibility of training and } \\
\text { education. }\end{array}$ & Leadership & 0.967 & $\begin{array}{l}0.847 \\
0.787 \\
0.768\end{array}$ & $\begin{array}{l}0.870 \\
0.871 \\
0.862 \\
0.925 \\
0.937 \\
0.914 \\
0.889 \\
0.885\end{array}$ \\
\hline \multicolumn{5}{|c|}{ KMO $=0.919 ;$ Bartlett's Test of Sphericity: Approx. Chi-Square $=13416.452, \mathrm{df}=36, \mathrm{p}<0.01$} \\
\hline $\begin{array}{l}\text { The presence of age } \\
\text { discrimination is not felt among } \\
\text { employees. } \\
\text { In the company, we do not feel } \\
\text { the presence of age } \\
\text { stereotypes. } \\
\text { There is no competition between } \\
\text { older and younger employees in } \\
\text { terms of who does better work. } \\
\text { We cooperate very well with } \\
\text { colleagues in the performance } \\
\text { of our tasks. } \\
\text { Employees appreciate the work } \\
\text { of our colleagues. } \\
\text { In case of conflict, we solve the } \\
\text { problem together and for the } \\
\text { common benefit. } \\
\text { In the company, mutual trust } \\
\text { and cooperation prevail. }\end{array}$ & $\begin{array}{l}\text { Employee } \\
\text { relations }\end{array}$ & 0.951 & $\begin{array}{l}0.757 \\
0.714 \\
0.723 \\
0.855 \\
0.832 \\
0.842\end{array}$ & $\begin{array}{l}0.879 \\
0.886 \\
0.779 \\
0.791 \\
0.903 \\
0.901 \\
0.922\end{array}$ \\
\hline
\end{tabular}

Source: Authors' calculation. 
Table 1 Factor analysis results - Continued

\begin{tabular}{|c|c|c|c|c|}
\hline Statement & Factor label & $\begin{array}{c}\text { Cronbach's } \\
\text { alpha }\end{array}$ & Communalities & $\begin{array}{l}\text { Factor } \\
\text { loadings }\end{array}$ \\
\hline $\begin{array}{l}\text { At my workplace, I am satisfied } \\
\text { with the working hours and } \\
\text { distribution of work obligations. } \\
\text { In this company, I am satisfied } \\
\text { with the balance between my } \\
\text { work and private life. } \\
\text { I am satisfied with the level of } \\
\text { self-regulation of work speed } \\
\text { that is enabled. } \\
\text { I am satisfied with the provision } \\
\text { of job-sharing, which reduces } \\
\text { the burden on the workplace. } \\
\text { I am satisfied with the } \\
\text { interpersonal relationships in the } \\
\text { company. } \\
\text { I am satisfied with the leadership } \\
\text { in the company. } \\
\text { I am satisfied with the } \\
\text { intergenerational cooperation } \\
\text { and, thus, the distribution of work } \\
\text { in the company. }\end{array}$ & $\begin{array}{l}\text { Work } \\
\text { satisfaction } \\
\text { of older } \\
\text { employees }\end{array}$ & 0.960 & $\begin{array}{l}0.818 \\
0.712 \\
0.782 \\
0.746 \\
0.839 \\
0.824 \\
0.827\end{array}$ & $\begin{array}{l}0.904 \\
0.803 \\
0.884 \\
0.843 \\
0.911 \\
0.907 \\
0.910\end{array}$ \\
\hline KMO = 0.930; Bartlett's Test of Sphe & rity• Annrox & Sauare $=7$ & $509, \mathrm{df}=21$ & 0.01 \\
\hline $\begin{array}{l}\text { I do my work with passion. } \\
\text { I am engaged in the quality of } \\
\text { my work. } \\
\text { I am engaged to achieve } \\
\text { successful business results. } \\
\text { I feel connection with the } \\
\text { company in which I work. } \\
\text { I am aware of the importance of } \\
\text { innovation for our company and } \\
\text { I am helping to develop the } \\
\text { company. } \\
\text { I trust in my colleagues and the } \\
\text { manager. } \\
\text { I feel that my work and job are } \\
\text { important. } \\
\text { I am proud to be employed in } \\
\text { this company. } \\
\text { I believe in the successful } \\
\text { development and operation of } \\
\text { the company. }\end{array}$ & $\begin{array}{c}\text { Work } \\
\text { engagement } \\
\text { of older } \\
\text { employees }\end{array}$ & 0.964 & $\begin{array}{l}0.862 \\
0.847 \\
0.840 \\
0.789 \\
0.790 \\
0.843 \\
0.832 \\
0.786 \\
0.796\end{array}$ & $\begin{array}{l}0.948 \\
0.936 \\
0.935 \\
0.913 \\
0.927 \\
0.933 \\
0.927 \\
0.911 \\
0.934\end{array}$ \\
\hline
\end{tabular}

Source: Authors' calculation.

According to Kock (2016), SEM is based on the linear or non-linear connections between constructs. The results obtained by WarpPLS 6.0 show that the observed links in our model are non-linear. Key quality assessment indicators of research model are presented in Table 2. 
Table 2 Model fit and quality indicators

\begin{tabular}{|l|c|c|}
\hline \multicolumn{1}{|c|}{ Quality indicators } & $\begin{array}{c}\text { Criterion of quality } \\
\text { indicators }\end{array}$ & $\begin{array}{c}\text { Calculated values of } \\
\text { indicators of model }\end{array}$ \\
\hline Average path coefficient (APC) & $\mathrm{p}<0.05$ & $0.638, \mathrm{p}<0.001$ \\
Average R-squared (ARS) & $\mathrm{p}<0.05$ & $0.897, \mathrm{p}<0.001$ \\
Average adjusted R-squared (AARS) & $\mathrm{p}<0.05$ & $0.897, \mathrm{p}<0.001$ \\
Average block variance inflation factor & $\mathrm{AVIF}<5.0$ & 2.096 \\
(AVIF) & $\mathrm{AFVIF}<5.0$ & 2.204 \\
Average full collinearity VIF (AFVIF) & GoF $\geq 0.1$ (low) \\
Goodness-of-fit (GoF) & GoF $\geq 0.25$ (medium) & 0.842 \\
Sympson's paradox ratio (SPR) & GoF $\geq 0.36$ (high) & 1.000 \\
R-squared contribution ratio (RSCR) & SPR $\geq 0.7$ & 1.000 \\
Statistical suppression ratio (SSR) & RSCR $\geq 0.9$ & 1.000 \\
Nonlinear causality direction ratio & SSR $\geq 0.7$ & 1.000 \\
(NLBCD) & NLBCD $\geq 0.7$ & \\
\hline
\end{tabular}

Source: Authors' calculation.

Table 2 shows that the indicators APC, ARS, AARS are statistically significant ( $p<$ 0.001 ), and the indicators AVIF and AFVIF are lower than 5.0 and are suitable. Indicator GoF shows the power of the underlying conceptual model (Kock, 2016), and the results of indicator GoF show that the model is highly appropriate. The values of indicators SPR, RSCR, SSR and NLBCD are higher than the minimal prescribed values and are suitable.

Table 3 Indicators of quality of structural model

\begin{tabular}{|l|c|c|c|c|c|c|c|}
\hline \multicolumn{1}{|c|}{ Constructs } & Cronbach's a & CR & AVE & R $^{2}$ & Adj. R & Q $^{2}$ & VIF \\
\hline Leadership & 0.976 & 0.979 & 0.808 & $(-)$ & $(-)$ & $(-)$ & 1.473 \\
Employee relations & 0.948 & 0.957 & 0.736 & $(-)$ & $(-)$ & $(-)$ & 1.687 \\
$\begin{array}{l}\text { Work satisfaction of } \\
\text { older employees }\end{array}$ & 0.972 & 0.975 & 0.768 & 0.466 & 0.441 & 0.473 & 2.529 \\
$\begin{array}{l}\text { Work engagement of } \\
\text { older employees }\end{array}$ & 0.984 & 0.985 & 0.850 & 0.449 & 0.442 & 0.461 & 2.361 \\
\hline
\end{tabular}

Note: (-) values cannot be calculated because the construct is a baseline Source: Authors' calculation.

Table 3 indicates that the values of the latent variables' $R^{2}$, adjusted $R^{2}$ and $Q^{2}$ coefficients are greater than zero. Composite reliabilities (CR) for all four constructs are greater than 0.7. Also, values of AVE for all four constructs are greater than 0.5. As all CR values were higher than AVE values, the authors confirmed the convergent validity for all the constructs studied. The VIF values ranged between 1.473 and 2.529 (VIF < 5.0), providing confidence that the structural model results were not affected by collinearity. The results of SEM and structural coefficients of links of the basic structural model are presented in Table 4. In addition, Figure 1 presents the conceptual model with the values of path coefficients. Figure 1 shows that leadership has the highest impact on the work satisfaction of older employees in comparison with employee relations, but both have positive impact on work satisfaction of older employees. 
Table 4 Standardized Path Coefficients for Proposed Model

\begin{tabular}{|l|l|l|c|c|c|}
\hline $\begin{array}{c}\text { Hypothesized } \\
\text { path }\end{array}$ & \multicolumn{1}{|c|}{$\begin{array}{c}\text { Link } \\
\text { direction }\end{array}$} & $\begin{array}{c}\text { Shape of } \\
\text { link }\end{array}$ & $\begin{array}{c}\text { Path coefficient } \\
(\mathrm{Y})\end{array}$ & $\begin{array}{c}\text { Effect size } \\
\left(f^{2}\right)\end{array}$ & $\begin{array}{c}\text { Standard } \\
\text { error }\end{array}$ \\
\hline LE $\rightarrow$ WS & Positive & Nonlinear & $0.434^{* * *}$ & 0.206 & 0.032 \\
ER $\rightarrow W S$ & Positive & Nonlinear & $0.340^{* * *}$ & 0.213 & 0.034 \\
$W S \rightarrow W E$ & Positive & Nonlinear & $0.654^{* * *}$ & 0.419 & 0.083 \\
\hline
\end{tabular}

Note: ${ }^{* * *} \mathrm{p}<0.001$; LE - leadership; ER - employee relations; WS - work satisfaction of older employees; WE - work engagement of older employees

Source: Authors' calculation.

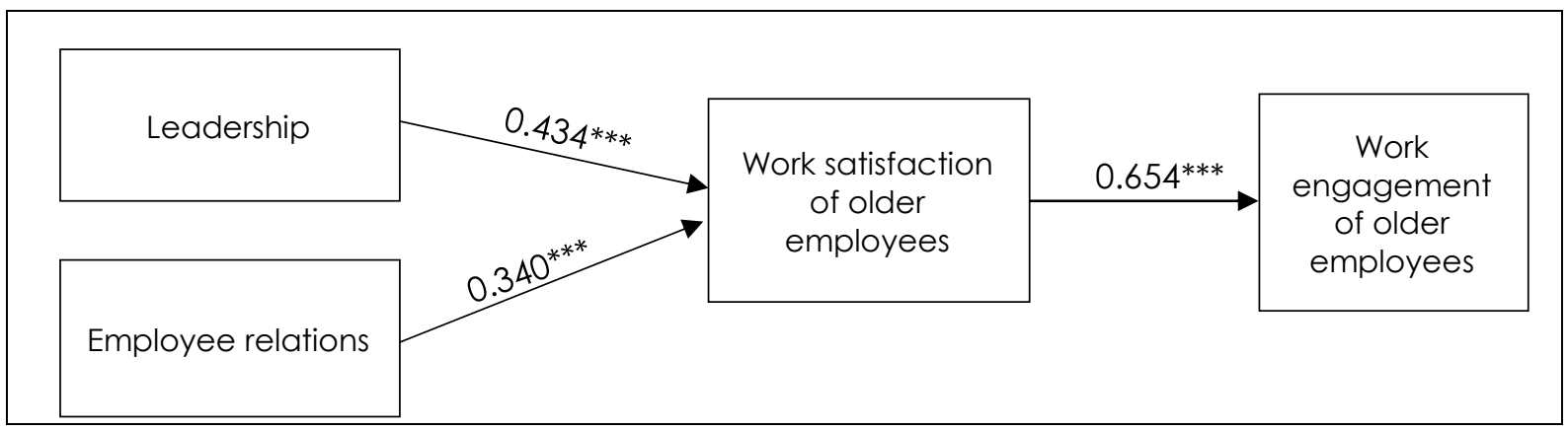

Figure 1 Conceptual model of managing older employees with the values of path coefficients

Note: ${ }^{* * *} p<0.001$

Source: Authors' creation.

The results in Table 4 show that leadership has a positive impact on the work satisfaction of older employees (LE $\rightarrow E S=0.434, \mathrm{P}<0.001$ ) in financial service companies. The value of Cohen's coefficient $\left(f^{2}=0.206\right)$ is greater than 0.15 and shows that the impact of predictive latent variables is of medium strength. In addition, employee relations have a positive impact on the work satisfaction of older employees $(E R \rightarrow E S=0.340, p<0.001)$. The value of Cohen's coefficient $\left(f^{2}=0.213\right)$ shows that the impact of predictive latent variables is of medium strength. The results in Table 4 show that the work satisfaction of older employees has a positive impact on the work engagement of older employees $(E S \rightarrow W E=0.654, p<0.001)$. The value of Cohen's coefficient ( $f^{2}=0.419$ ) shows that the effect of predictive latent variables is of high strength. The results show that there is a non-linear connection between the individual constructs. the authors therefore verified and confirmed hypothesis 1 (leadership has a significant positive impact on the work satisfaction of older employees in financial service companies in Slovenia), hypothesis 2 (employee relations have a significant positive impact on the work satisfaction of older employees in financial service companies in Slovenia), and hypothesis 3 (employee satisfaction has a significant positive impact on the work engagement of older employees in financial service companies in Slovenia).

\section{Conclusion}

The review of contemporary literature allows the conclusion that the population is progressively ageing. Demographic changes lead to older employees playing a prominent role in the workforce in the near future. Employers need to allow older employees to have friendly and healthy work environment, which leads to higher work engagement. Thus, employers are responsible to create a healthy and friendly working environment with working conditions that are conducive to a full life of work and that support the mental and physical health of employees. 
Based on the results, the authors found that leadership and employee relations have a significant positive impact on the work satisfaction of older employees in financial companies in Slovenia, as well as that work satisfaction has a significant positive impact on the work engagement of older employees. Some authors found that leadership and employee relations have a positive effect on the work satisfaction of older employees and that the work satisfaction of older employees has a positive effect on the work engagement of older employees, but their research was not limited to medium sized and large financial service companies. The results show that human resource managers should foster mainly good relationship between employees and superiors, prevailing trust and cooperation between employees and satisfaction with the interpersonal relationships in order to achieve higher older employees work engagement.

Some research shows that employees in the finance sector are comparable to employees in other sectors according to the importance they place on a variety of job features. Interesting work, potential for advancement, job security, ability to help others, social usefulness, and autonomy at work are some of the important concerns for financial sector employees.

For employee relations it is important to build trust between age-diverse colleagues in financial companies. Thus, it is important that age-diverse employees share a healthy relation with each other at the workplace, because the company becomes a happy place to work, if the employees work together as a good family.

According to our findings, it is also almost equally important that employers are ready to listen the employees and that employers inform employees about their decisions concerning the organization. It is possible to conclude that good relationship between leaders and employees is one of the most important components influencing employees work engagement.

Employees who know they have the opportunity to improve their skills and rise within the company may be more satisfied with their work, which lead to higher work engagement. Employers should create a friendlier working environment, because this leads to higher job satisfaction among employees, and leads to increased productivity and a higher rate of engagement.

The main scientific contribution of this paper is reflected in the analysis of the structural equation model of the older employees' human resources management in financial services companies. It is based on the first survey, conducted among older employees in financial services companies in Slovenia. Results can help financial service companies to better understand and manage their older employees. Moreover, results can be useful for managers who want to create an adequate working environment for older employees and increase work engagement of older employees.

Our study is limited to the focus of older employees in Slovenia in medium-sized and large financial services companies. As an opportunity for future research, the authors recommend an upgrade of the measurement instrument with new constructs in the area of older employees. Also, our further research refers to analyzing different constructs (for example, occupational stress, burnout and work engagement) with structural equation modeling (SEM).

\section{References}

1. Abugre, J. (2017). Relations at workplace, cynicism and intention to leave. International Journal of Organizational Analysis, Vol. 25, No. 2, pp. 198-216.

2. Amagoh, F. (2009). Leadership development and leadership effectiveness. Management Decision, Vol. 47, No. 6, pp. 989-999. 
3. Anitha, J. (2014). Determinants of employee engagement and their impact on employee performance. International Journal of Productivity and Performance Management, Vol. 63, No. 3, pp. 308-323.

4. Aristovnik, A., Jaklič, K. (2013). Job Satisfaction of Older Workers as a Factor of Promoting Labour Market Participation in the EU: The Case of Slovenia. Available at http://www.rsp.hr/ojs2/index.php/rsp/article/viewFile/1126/1227 [01 October 2019].

5. Aver Antoncic, J., Antoncic, B. (2011). Employee satisfaction, intrapreneurship and firm growth: a model. Industrial Management \& Data Systems, Vol. 111 , No. 4, pp. 589-607.

6. Avery, D. R., McKay, P. F., Wilson, D. C. (2007). Engaging the aging workforce: The relationship between perceived age similarity, satisfaction with coworkers, and employee engagement. Journal of Applied Psychology, Vol. 92, No. 6, pp. 1542-1556.

7. Bakker, A.B., Demerouti, E. (2009). The crossover of work engagement between working couples: a closer look at the role of empathy. Journal of Managerial Psychology, Vol. 24, No. 3, pp. 220-236.

8. Beazley, A., Ball, C. and Vernon, K. (2017). Workplace Age Diversity: The Employers' Perspectives. Available at https://www.emerald.com/insight/content/doi/10.1 108/978-178714-638-920171012/full/htmlefullsc=1 [29 September 2019].

9. Brooke, L. (2003). Human resource costs and benefits of maintaining a mature-age workforce. International Journal of Manpower, Vol. 24, No. 3, pp. 260-283.

10.Chan, S. (2019). Participative leadership and job satisfaction. Leadership \& Organization Development Journal, Vol. 40, No. 3, pp. 319-333.

11.Cheung, F., Wu, A. (2013). Older workers' successful aging and intention to stay. Journal of Managerial Psychology, Vol. 28, No. 6, pp. 645-660.

12.Chiesa, R., Toderi, S., Dordoni, P., Henkens, K., Fiabane, E. and Setti, I. (2016). Older workers: stereotypes and occupational self-efficacy. Journal of Managerial Psychology, Vol. 31, No. 7, pp. 1152-1166.

13.Chronbach, L. J. (1951). Coefficient alpha and the internal structure of tests. Psychometrika, Vol. 16, No. 3, pp. 297-334.

14. Cleveland, J. N., Lim, A. S. (2007). Employee age and performance in organizations. In K. S. Shultz \& G. A. Adams (Eds.), Applied psychology series. Aging and work in the 21 st century, pp. 109-137, Mahwah, NJ, US: Lawrence Erlbaum Associates Publishers.

15.Davies, E., Hanley, K., Jenkins, A., Chan, C. (2017). Learning and training for older workers. Available at https://www.emerald.com/insight/content/doi/10.1108/978-1-78714-638920171009/full/html [29 September 2019].

16.Dhamija, P., Gupta, S., Bag, S. (2019). Measuring of job satisfaction: the use of quality of work life factors. Benchmarking. An International Journal, Vol. 26, No. 3, pp. 871-892.

17.Egan, T., Yang, B., Bartlett, K. (2004). The effects of organizational learning culture and job satisfaction on motivation to transfer learning and turnover intention. Human Resource Development Quarterly, Vol. 15, No. 3, pp. 279-301.

18.Fay, M. J., Kline, S. L. (2011). Co-worker relationships and informal communication in highintensitytelecommuting. Journal of Applied Communication Research, Vol. 39, No. 1, pp. 144-163.

19.Ford, D. (2011). Managing business relations. Wiley, New York.

20.Greller, M. M., Stroh, L. K. (2004). Making the most of late careers for employers and workers themselves: becoming elders not relics. Organizational Dynamics, Vol. 33 No. 5, pp. 202-214.

21.Guglielmi, D., Avanzi, L., Chiesa, R., Mariani, M. G., Bruni, I., Depolo, M. (2016). Positive Aging in Demanding Workplaces: The Gain Cycle between Job Satisfaction and Work Engagement. Frontiers in psychology, Vol. 15, No. 7, pp. 1-10.

22. Gunnigle, P., Turner, T., Morley, M. (1998). Strategic integration and employee relations: the impact of managerial styles. Employee Relations, Vol. 20, No. 2, pp. 115-131.

23.Hair, J. F., Black, W. C., Babin, B. J., Anderson, R. E. (2010). Multivariate data analysis. Upper Saddle River, Pearson Prentice Hall.

24. Hayday, S. (2003). Questions to Measure Commitment and Job Satisfaction. Available at https://www.employment-studies.co.uk/system/files/resources/files/mp19.pdf [15 September 2019]. 
25. Hennekam, S. (2016). Competencies of older workers and its influence on career success and job satisfaction. Employee Relations, Vol. 38, No. 2, pp. 130-146.

26. Hertel, G., van der Heijden, B., de Lange, A., Deller, J. (2013). Facilitating age diversity in organizations - part II: managing perceptions and interactions. Journal of Managerial Psychology, Vol. 28, No. 7/8, pp. 857-866.

27.Hu, Y., Yang, Y., Islam, M. (2010). Leadership behavior, satisfaction, and the balanced scorecard approach. International Journal of Commerce and Management, Vol. 20, No. 4, pp. 339-356.

28.IImarinen, J. (2001). Aging workers. Occupational \& Enviromental Medicine, Vol. 55, No. 8, pp. 546-552.

29.Kaiser, H. F. (1974). An index of factorial simplicity. Psychometrika, Vol. 39, No. 1, pp. 31-36.

30.Kock, N. (2015). WarpPLS 5.0 User Manual. ScriptWarp Systems, Laredo, Texas. Available at http://cits.tamiu.edu/WarpPLS/UserManual_v_5_0.pdf [15 September 2019].

31.Kock, N. (2016). Advantages of nonlinear over segmentation analyses in path models. International Journal of e-Collaboration, Vol. 12, No. 4, pp. 1-6.

32.Kooij, D. T. A. M., De Lange, A. H., Jansen, P. G. W., Kanfer, R., Dikkers, J. S. E. (2011). Age and work-related motives: Results of a meta-analysis. Journal of Organizational Behavior, Vol. 32, No. 2., pp. 197-225.

33.Kooij, D. T. A. M., Guest, D., Clinton, M., Knight, T., Jansen, P., Dikkers, J. (2013). How the impact of HR practices on employee well-being and performance changes with age. Human Resource Management Journal, Vol. 23, No. 1, pp. 18-35.

34.Kooij, D., Van De Voorde, K. (2015). Strategic HRM for older workers. Available at https://www.researchgate.net/publication/266393824_Strategic_HRM_for_older_workers [01 October 2019].

35.Kulik, C. T., Ryan, S., Harper, S., George G. (2014). Aging populations and management. Academy of Management Journal, Vol. 57, No. 4, pp. 929-935

36.Lu, L., Lu, A., Gursoy, D., Neale, N. (2016). Work engagement, job satisfaction, and turnover intentions. International Journal of Contemporary Hospitality Management, Vol. 28, No. 4, pp. 737-761.

37.Manly, B. F. (2005). Multivariate statistical methods: A primer. Chapman \& Hall/CRC, New York.

38.May, G. (2004). The future of financial services in Europe. Foresight, Vol. 6 No. 5, pp. 271-280.

39. Moen, P., Kojola, E., Schaefers, K. (2017). Organizational Change Around an Older Workforce. Gerontologist, Vol. 57, No. 5, pp. 847-856.

40.Naegele, G., Walker, A. (2006). A guide to good practice in age management. Office for Official Publications of the European Communities, Luxembourg.

41.Ning, W., Alikaj, A. (2019). The influence of age on the job resources-engagement relationship. International Journal of Organizational Analysis, Vol. 27, No. 4, pp. 1218-1238.

42. OECD (2000). OECD employment outlook. Ageing of the labour force in OECD countries. Available at https://www.ilo.org/wcmsp5/groups/public/--ed_emp/documents/publication/wcms_142281.pdf [03 September 2019].

43.Peeters, M., van Emmerik, H., Peeters, M., van Emmerik, H. (2008). An introduction to the work and well-being of older workers. Journal of Managerial Psychology, Vol. 23 No. 4, pp. 353363.

44.Profili, S., Innocenti, L., Sammarra, A. (2017). A Conceptual Framework of Age Diversity Climate. Available https://www.researchgate.net/publication/318880828_A_Conceptual_Framework_of_Age _Diversity_Climate [29 September 2019].

45.Robinson, D., Perryman, S., Hayday, S. (2004). The drivers of employee engagement. Available at http://www.employmentstudies.co.uk/report-summary-drivers-employeeengagement [1 1 September 2019].

46.Schaufeli, W. B., Salanova, M., González-Romá, V., Bakker, A. B. (2002). The measurement of engagement and burnout: A two sample confirmatory factor analytic approach. Journal of Happiness Studies: An Interdisciplinary Forum on Subjective Well-Being, Vol. 3, No. 1, pp. 71-92 
47.Smyer, M. A., Pitt-Catsouphes, M. (2007). The meanings of work for older workers. Generations, Vol. 31 No. 1, pp. 23-30.

48.Sweet, S., Pitt-Catsouphes, M. (2010). Talent Pressures and the Aging Workforce: Responsive Action Steps for the Finance and Insurance Sector. Available at https://www.bc.edu/content/dam/files/research_sites/agingandwork/pdf/publications/T MISR07_Financelnsurance.pdf [03 September 2019].

49.Tabachnick, B. G., Fidell, L. S. (2013). Using multivariate statistics. Pearson Education, Boston.

50.Veingerl Čič, Ž., Šarotar Žižek, S., Čančer, V. (2017). Nonlinear connections in structural equation modeling: the case of service sector companies in Slovenia. In: Zadnik Stirn, L., Kljajić Borštnar, M., Žerovnik, J., Drobne, S. (eds.). SOR '17 proceedings. Ljubljana: Slovenian Society Informatika, Section for Operational Research, pp. 350-355.

51.Warr, P. (1994). Age and employment. In Triandis, H. C., Dunnette, M. D., Hough, L. M. (Eds.), Handbook of industrial and organizational psychology (pp. 485-550). Palo Alto, CA, US: Consulting Psychologists Press.

52. Watt, J. D., Piotrowski, C. (2008). Organisational change cynicism: a review of the literature and intervention strategies. Organisation Development Journal, Vol. 26, No. 3, pp. 23-31.

53. Yang, T., Shen, Y. M., Zhu, M., Liu, Y. Deng, J., Chen Q., See, L. C. (2015). Effects of co-worker and supervisor support on job stress and presenteeism in an aging workforce: A structural equation modelling approach. International Journal of Environmental Research and Public Health, Vol. 13, No. 1, pp. 1-9.

54.Zacher, H., Kooij, D. T. A. M., Beier, M. E. (2018). Active aging at work: contributing factors and implications for organizations. Organizational Dynamics, Vol. 47 No. 1, pp. 37-45.

\section{About the authors}

Maja Rožman has acquired her Master degree at the Faculty of Economics and Business in Maribor at the Department of Finance and the PhD at the Department of Management and Organization. She is also an assistant at the Faculty of Economics and Business at the Department of Quantitative Economic Analyses. Her research work is focused on contemporary management problems in organisations, especially in the field of human

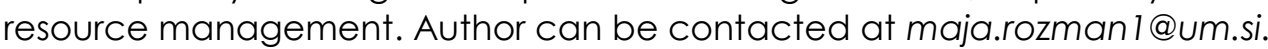

Vesna Čančer holds a PhD in economic and business sciences, and is a full professor of quantitative methods in business science at the University of Maribor's Faculty of Economics and Business. Her research focuses on decision analysis with an emphasis on multi-criteria decision-making, creative problem solving, and research methods, together with their interdisciplinary applications. Author can be contacted at vesna.cancer@um.si. 